\title{
Managing Fusarium Wilt of Watermelon with Delayed Transplanting and Cultivar Resistance
}

Anthony P. Keinath, ${ }^{\dagger}$ Clemson University, Coastal Research and Education Center, Charleston, SC 29414; Timothy W. Coolong, Department of Horticulture, University of Georgia, Tifton, GA 31793; Justin D. Lanier, Enza Zaden USA, Cordele, GA 31015; and Pingsheng Ji, Department of Plant Pathology, University of Georgia, Tifton, GA 31793

\begin{abstract}
Fusarium wilt of watermelon caused by Fusarium oxysporum f. sp. niveum is a serious, widespread disease of watermelon throughout the southern United States. To investigate whether soil temperature affects disease development, three cultivars of triploid watermelon were transplanted March 17 to 21, April 7 to 11, and April 26 to May 2 in 2015 and 2016 at Charleston, SC, and Tifton, GA into fields naturally infested with $F$. oxysporum $\mathrm{f}$. sp. niveum. Incidence of Fusarium wilt was lower with late-season than with early and midseason transplanting in all four experiments $(P \leq 0.01)$. Cultivar Citation had more wilted plants than the cultivars Fascination and Melody in three of four experiments $(P \leq 0.05)$. In South Carolina, planting date did not affect

weight and number of marketable fruit $\geq 4.5 \mathrm{~kg}$ apiece. In Georgia in 2016, weight and number of marketable fruit were greater with late transplanting than with early and midseason transplanting. In both states, yield and value for Fascination and Melody were higher than for Citation. Soil temperature averaged over the 4-week period after transplanting was negatively correlated with disease incidence for all four experiments $(r=-0.737, P=0.006)$. Transplanting after midApril and choosing a cultivar with resistance to $F$. oxysporum $\mathrm{f}$. sp. niveum race 1, like Fascination, or tolerance, like Melody, can help manage Fusarium wilt of watermelon and increase marketable yields in the southern United States.
\end{abstract}

Fusarium wilt of watermelon (Citrullus lanatus var. lanatus (Thunb.) Matsum. \& Nakai), caused by Fusarium oxysporum Schltdl.:Fr. f. sp. niveum, is one of the most serious diseases of watermelon worldwide (Martyn 2014). Although four races, designated $0,1,2$, and 3 , have been reported, race 2 is the most important race, because it is widely distributed within the United States, including South Carolina and Georgia (Keinath and DuBose 2009; Martyn 2017; Petkar and Ji 2017; Zhou and Everts 2003; Zhou et al. 2010). Diploid and triploid watermelon cultivars with resistance to race 1 are commercially available and used widely in the southern United States (Kemble et al. 2018). Although sources of resistance to race 2 have been identified in Citrullus lanatus var. citroides, triploid watermelon cultivars that possess this resistance are not yet available (Wechter et al. 2012). Race 3 of $F$. oxysporum f. sp. niveum was recently identified in Florida, Georgia, and Maryland (Amaradasa et al. 2018; Petkar and Ji 2017; Zhou et al. 2010). In place of watermelon cultivars resistant to Fusarium wilt, grafting susceptible scions onto interspecific hybrid squash (Cucurbita maxima Duch. ex Lam. $\times$ C. moschata Duch. ex Poir) and bottle gourd (Lagenaria siceraria (Molina) Standl.) rootstocks protects grafted plants from Fusarium wilt (Davis et al. 2008; Keinath and Hassell 2014b; Martyn 2017). Both rootstock genera are resistant to $F$. oxysporum f. sp. niveum races 1 and 2 (Keinath and Hassell 2014a; Yetış1r et al. 2003). However, grafted transplants are considerably more expensive than nongrafted seedlings (Keinath and Hassell 2014b), and some growers are reluctant to invest so much in a watermelon crop at the beginning of a growing season. Thus, alternative measures to manage Fusarium wilt are still needed.

${ }^{\dagger}$ Corresponding author: A. P. Keinath; E-mail: tknth@clemson.edu

Funding: This material is based upon work supported by National Institute of Food and Agriculture, U.S. Department of Agriculture under award number 2014-51181-22471 and project number GEO00788. Technical Contribution No. 6656 of the Clemson University Experiment Station.

Accepted for publication 24 June 2018.

C 2019 The American Phytopathological Society
Surprisingly little research has been done on the effects of temperature on Fusarium wilt of watermelon after the initial reports (Porter 1932; Walker 1941). Porter observed an increase in Fusarium wilt incidence in young plants when air temperatures increased above $24^{\circ} \mathrm{C}$, which he related to increased transpiration stress on diseased plants. In the experiment done in California in 1931, he noted that soil temperatures were $\geq 23.5^{\circ} \mathrm{C}$ at 1 - to 30 -cm depths. Walker (1941) conducted experiments in temperature tanks at a range of soil temperatures between 18.5 and $39^{\circ} \mathrm{C}$ and collected data on Fusarium wilt and watermelon growth. He noted that disease incidence was maximum at $27^{\circ} \mathrm{C}$ in most experiments, but a similarly high incidence occurred at 29 and $30^{\circ} \mathrm{C}$ in two of the four experiments. Subsequently, $27^{\circ} \mathrm{C}$ has been used as an upper temperature threshold for optimum disease development (Martyn 2017).

Triploid watermelon cultivars are characterized by the sizes (average weight) of fruit they are expected to produce (Table 1). Triploid watermelons are marketed in three main size categories, 60-count (small), 45-count (medium), and 36-count (large), which are based on the average number of fruit per $317.5-\mathrm{kg}$ bin, with $4.54 \mathrm{~kg}$ being the smallest size acceptable to produce brokers, based on information from the National Watermelon Promotion Board (www.watermelon. org). The 45-count size is the preferred size when fruit are plentiful, but when fruit are scarce, all three sizes are equally desirable.

Fusarium wilt caused by race 2 reduced the number of fruit per hectare and the percentage of fruit in the 45-count and 36-count categories for triploid watermelon cultivar Fascination, which is resistant to race 1 (Keinath and Hassell 2014b). In one of two years, the weight of 45-count fruit also was reduced. In Delaware, triploid watermelon cultivars Fascination and Melody were evaluated in soil naturally infested predominantly with race 1 but also race 2 (Everts and Hochmuth 2011, 2012). In 2010 and 2011, both cultivars had fewer wilted plants than the most susceptible cultivars in the tests, and wilt ratings and weight of fruit harvested did not differ between Fascination and Melody. In 2011, Fascination and Melody were the two highest yielding cultivars, by weight, among the 26 cultivars tested, but fruit were harvested only once. Detailed information on the yield response of triploid watermelon grown in $F$. oxysporum f. sp. niveum-infested soil is not currently available. Such information would help growers select cultivars that have the greatest yield potential, even when grown in infested soil. The objectives of this study were to determine i) if planting date affected the incidence of 
Fusarium wilt and the yield of triploid watermelons, and ii) the yield response, including the size distribution, of triploid cultivars grown in soil infested with $F$. oxysporum $\mathrm{f}$. sp. niveum race 2.

\section{Materials and Methods}

In South Carolina, experiments were done at the Clemson University Coastal Research and Education Center in Charleston $\left(32.47304^{\circ} \mathrm{N} ; 80.41116^{\circ} \mathrm{W}\right)$. The soil types in the field are Charleston loamy fine sand and Yonges loamy fine sand. Blocks were assigned to one soil type when possible. The field has been cropped to watermelon yearly since 2005 and is naturally infested with $F$. oxysporum f. sp. niveum races 1 and 2 (Keinath and DuBose 2009). The field was seeded to rye (Secale cereale) in the fall before both experiments. The field was disked twice, and $560 \mathrm{~kg} / \mathrm{ha}$ of $15 \mathrm{~N}-0 \mathrm{P}-12.5 \mathrm{~K}$ fertilizer was applied. Raised beds were shaped $0.9 \mathrm{~m}$ wide on $2.7-\mathrm{m}$ centers, sprayed with the pre-emergent herbicides S-metolachlor and halosulfuron, and covered with black polyethylene mulch on 22 February 2015 and 9 March 2016.

The experimental design was a split-plot with four and five replications in 2015 and 2016, respectively. In both experiments, the main plot treatment was planting date, and the subplot treatment was cultivar (Table 1). Six weeks before the transplanting dates, seeds of triploid watermelon cultivars Fascination, Melody (Syngenta Seeds, Woodland, CA), and Citation (Sakata Seed America, Morgan Hill, CA) were sown on 3 and 24 February and 16 March in both 2015 and 2016 into 98-cell flats containing Fafard 3B potting mix (Sun Gro Horticulture, Agawam, MA). One day prior to transplanting, seedlings were drenched with propamocarb hydrochloride at 0.72 $\mathrm{g} /$ liter to reduce Pythium damping-off. Seedlings were transplanted on 18 March and 8 and 28 April 2015 and 17 March and 7 and 26 April 2016 into single-row field plots. Plots were $15.2 \mathrm{~m}$ long with 14 plants per plot spaced $1.1 \mathrm{~m}$ apart. Plots were separated by 3.0$\mathrm{m}$ of unplanted space within rows. Five SP-6 pollenizers (Syngenta Seeds) were transplanted per plot, one at each end and one between every third plant. Soil temperatures in mulched beds were recorded with two Watchdog external temperature sensors (Spectrum Technologies, Aurora, IL) placed $5 \mathrm{~cm}$ deep in plots in two blocks. Liquid $8 \mathrm{~N}-0-8 \mathrm{P}$ fertilizer with minor elements was applied to the field throughout the season through the drip irrigation system. The rates of $\mathrm{N}$ and $\mathrm{K}$ were adjusted with watermelon growth stage (Keinath et al. 2010). Currently registered fungicides were applied every 7 to 10 days to prevent gummy stem blight, powdery mildew, and downy mildew in both years and anthracnose in 2016 only. Plots were checked for arthropods, and miticides or insecticides were applied when two-spotted spider mites, aphids, cucumber beetles, armyworms, or leaf-footed bugs (2015 only) were observed (Kemble et al. 2018).

In Georgia, the experiments were done outside Cordele $\left(31.95709^{\circ} \mathrm{N}\right.$, $83.811661^{\circ} \mathrm{W}$ ), where the soil type is Tift loamy sand. The research site has had continuous watermelon production for nearly 20 years and was known to be naturally infested with $F$. oxysporum f. sp. niveum race 2 . A rye cover crop was terminated using $1.54 \mathrm{~kg} / \mathrm{ha}$ glyphosate approximately 1 month prior to laying plastic. Immediately prior to laying plastic, $1,120 \mathrm{~kg} / \mathrm{ha}$ of fertilizer $(5 \mathrm{~N}-4.4 \mathrm{P}-$ $12.5 \mathrm{~K}$ ) was broadcast and incorporated into the soil to a depth of approximately $10 \mathrm{~cm}$. Raised beds were shaped $0.9 \mathrm{~m}$ wide on $1.8-\mathrm{m}$ centers and covered with 1.0-m-wide black polyethylene mulch on 10 March 2015 and 7 March 2016. After plastic was laid, plots were broadcast sprayed with the pre-emergent herbicides terbacil $(0.224 \mathrm{~kg} / \mathrm{ha})$, ethalfluralin $(0.43 \mathrm{~kg} / \mathrm{ha})$, and fomesafen $(0.21 \mathrm{~kg} / \mathrm{ha})$ and watered overhead with $3 \mathrm{~cm} / \mathrm{ha}$ to wash herbicide from plastic. The experimental design was a randomized complete block with three cultivars and three transplanting dates arranged in a factorial design. Watermelon seedlings were grown in 200-cell trays (Speedling, Ruskin, FL) in the greenhouse for 6 weeks using a peat-based soilless mix (Pro-Mix BX; Premier Tech, Riviere-duLoup, QC, Canada). Seeded trays were placed in a germination chamber ( 26 to $28^{\circ} \mathrm{C}, 90 \%$ relative humidity) for $48 \mathrm{~h}$ and then moved to a greenhouse for production. Temperature set points of $26 / 20^{\circ} \mathrm{C}$ (day/night) were used in the greenhouse. Plants were watered twice daily as needed and fertilized three times weekly after germination with a $150 \mathrm{mg} / \mathrm{liter}$ nitrogen $(\mathrm{N})$ solution (20N-4.4P-16.6K; Scotts, Marysville, OH). Seedlings were transplanted on 20 March, 10 April, and 1 May in 2015 and 21 March, 11 April, and 2 May 2016. Each plot consisted of two 4.6-m-long rows with five triploid plants per row spaced $0.9 \mathrm{~m}$ apart. Plots were separated by $2.7 \mathrm{~m}$ within rows. Four SP-6 pollenizers were transplanted per plot, after the third and fifth plants in each row. Three plots each of the Fusarium wilt differential cultivars Charleston Gray (resistant to $F$. oxysporum f. sp. niveum race 0) and Calhoun Gray (highly resistant to $F$. oxysporum $\mathrm{f}$. sp. niveum race 1 ) and pollenizer SP-6 (intermediate resistance to $F$. oxysporum $\mathrm{f}$. sp. niveum races 1 and 2) were planted in the field in each year at the first planting date (Bruton et al. 2010; Martyn 2017). Based on symptomatic plants of Charleston Gray, Calhoun Gray, and SP-6, F. oxysporum f. sp. niveum race 2 was present in the field. Four temperature sensors (WatchDog Button Logger, Spectrum Technologies Inc., Plainfield, IL) were placed in a plot in each replicate at a depth of $10 \mathrm{~cm}$ on the first transplanting date. Plots were overhead irrigated with a centerpivot irrigation system as is common in the region. At 4 or 6 weeks after the first transplanting in 2015 and 2016, respectively, $112 \mathrm{~kg} / \mathrm{ha}$ $46 \mathrm{~N}-0 \mathrm{P}-0 \mathrm{~K}$ (urea) supplemental fertilizer was applied broadcast. Maintenance fungicides and insecticides were applied every 10 to 14 days following University of Georgia Cooperative Extension Guidelines (Horton 2015).

At both locations, the total number of living plants and plants with symptoms of Fusarium wilt or Pythium stem and root rot were counted in each plot starting 2 weeks after transplanting and used to calculate incidence of Fusarium wilt. Pythium stem and root rot symptoms included stunting, i.e., a lack of primary vine elongation, severe wilting of all leaves and the growing point, root rot, and a water-soaked lesion on the stem just above the soil line. On young plants, Fusarium wilt was distinguished from symptoms of Pythium by checking for wilting of only the oldest leaves on plants without a stem lesion or root rot. Once vines began to elongate, typical symptoms of Fusarium wilt in the initial phase included wilting of basal leaves on one or two vines but rarely all vines of a plant. In 2015 in South Carolina, counts of symptomatic plants were made weekly from 1 April to 27 May, and a final count was done on 17 June, 10 ratings in all. In 2016 in South Carolina, disease incidence of Fusarium wilt and Pythium stem and root rot were recorded separately 13 times, weekly between 30 March and 5 May and then every 10 to 14 days between 18 May and 9 July, because new plants with symptoms of Fusarium wilt continued to appear after harvest began.

Table 1. Characteristics of triploid watermelon cultivars used in all four experiments in Georgia and South Carolina in 2015 and 2016

\begin{tabular}{|c|c|c|c|c|c|c|}
\hline \multirow[b]{2}{*}{ Cultivar } & \multirow[b]{2}{*}{ Source } & \multirow[b]{2}{*}{ Maturity (days) } & \multirow{2}{*}{$\begin{array}{c}\text { Fusarium oxysporum f. sp. niveum } \\
\text { resistance }\end{array}$} & \multicolumn{3}{|c|}{ Expected size distribution $^{\mathrm{x}}$} \\
\hline & & & & 60-count & 45-count & 36-count \\
\hline Citation & Sakata $^{y}$ & 78 & Susceptible & $85 \%$ & $15 \%$ & $0 \%$ \\
\hline Melody & Syngenta ${ }^{z}$ & 79 & Susceptible & $25 \%$ & $50 \%$ & $25 \%$ \\
\hline Fascination & Syngenta & 83 & Intermediate resistance to race 1 & $10 \%$ & $70 \%$ & $20 \%$ \\
\hline
\end{tabular}

${ }^{\mathrm{x}}$ Fruit classified as 60-count (small) weigh 4.54 to $6.12 \mathrm{~kg}, 45$-count (medium) weigh 6.17 to $7.94 \mathrm{~kg}$, and 36 -count (large) weigh 7.98 to $9.75 \mathrm{~kg}$ apiece. Size distributions obtained from N. Guner, Sakata, personal communication, and Syngenta web site referenced in footnote "z."

y http://sakatavegetables.com/vegetable/watermelon/watermelon-triploid/citation

${ }^{\mathrm{z}}$ www.syngenta-us.com/seeds/vegetables/watermelon/watermelon-comparison-chart.pdf 
Symptoms of Pythium stem and root rot were not observed later than 6 weeks after transplanting. In Georgia, counts of healthy and symptomatic plants were made weekly from 4 April to 18 May 2015 and then every 10 to 14 days between 27 May and 26 June, 10 ratings in all. In 2016 in Georgia, counts of healthy and symptomatic plants were made every 7 to 10 days between 22 April and 10 June, and a final count was done on 30 June, seven ratings in all. Area under the disease progress curve (AUDPC) values for Fusarium wilt were calculated from incidence ratings. Relative AUDPC was calculated as AUDPC values divided by the number days from transplanting to the last disease rating to standardize the time interval for the different transplanting dates.

In South Carolina, fruit were harvested weekly six times each year from 18 June until 29 July 2015 and from 20 June until 25 July 2016. Fruit were weighed individually and graded as being unblemished, diseased with symptoms of anthracnose or other fruit rot, damaged by wildlife, or sunburned. Unblemished watermelon fruit were harvested and weighed individually in Georgia on 7 July 2015 and 22 June, 3 July, and 14 July 2016. Weights of unblemished melons at both locations were sorted into five categories: extra small 2.27 to $4.53 \mathrm{~kg}$, small (60-count) 4.54 to $6.12 \mathrm{~kg}$, medium (45-count) 6.17 to $7.94 \mathrm{~kg}$, large (36-count) 7.98 to $9.75 \mathrm{~kg}$, and extra large (30count $) \geq 9.8 \mathrm{~kg}$ based on standard marketing size categories for triploid watermelon (National Watermelon Promotion Board). Large and extralarge categories were combined for analysis, because there were no extra-large fruit in 2015 and $<0.5$ extra-large fruit per plot in 2016. Triploid watermelon fruit $\geq 4.54 \mathrm{~kg}$ apiece are considered marketable in the retail trade (National Watermelon Promotion Board). Crop value was calculated with prices in South Carolina and Georgia for the harvest weeks in 2015 and 2016 provided by the National Watermelon Promotion Board (J. Hanselman, personal communication). In 2015, prices for South Carolina melons ranged from $\$ 0.26 / \mathrm{kg}$ for 60 -count melons on 18 June to $\$ 0.40 / \mathrm{kg}$ for 45 -count melons on 15 July. Between 18 June and 2 July 2015, prices were $\leq \$ 0.33 / \mathrm{kg}$, and between 17 and 29 July prices were $\geq \$ 0.35 / \mathrm{kg}$. In 2016 , prices in South Carolina were $\$ 0.35 / \mathrm{kg}$ for the entire 6-week harvest period for all melon sizes except for the week of 12 July, when the price was $\$ 0.33 / \mathrm{kg}$. In 2016 , prices in Georgia were $\$ 0.35 / \mathrm{kg}$ for 45 - and 60 -count melons for the weeks of 22 June and 3 July, and $\$ 0.31 / \mathrm{kg}$ for the week of 14 July. The MANOVA option in SAS PROC GLM was used to determine the effects of transplanting date, cultivar, and the interaction between these factors on fruit size in a multivariate analysis of variance with the weights of 60-, 45-, and 36-count melons. In addition, the percentage of fruit in each size class was compared with the expected percentage size distribution for each cultivar with $t$ tests. Too few fruit per plot were produced in Georgia to compare fruit sizes.

Statistical analysis. All data were checked for nonnormality using the Shapiro-Wilk W test. Based on the results, incidence ratings and percentage marketable fruit were transformed with arcsine of the square root; relative AUDPC, number of marketable fruit, weight of marketable fruit in South Carolina, and crop value were transformed with square root; and weight of marketable fruit in Georgia was transformed with the base-ten logarithm before analysis of variance. Mixed-model maximum likelihood analysis of variance was done with SAS PROC MIXED (SAS version 9.4, SAS, Inc., Cary, NC) with year, transplanting date, cultivar, and all interactions among these factors as fixed effects and block as a random effect. Data from Georgia and South Carolina were analyzed separately because of the different experimental designs used in the two locations. In models that included data from 2 years, a split-split-plot or splitplot analysis was used for data from South Carolina and Georgia, respectively, with year as the whole plot. When interactions were significant, the SAS SLICE option of the LSMEANS statement was used to compare levels of one treatment within levels of another treatment. Treatment means were separated with Fisher's protected least significant difference. Pearson correlation coefficients were calculated with SAS PROC CORR, and regression equations were calculated with SAS PROC REG between final disease incidence and soil temperatures.

\section{Results}

Fusarium wilt. Fusarium wilt was severe in 2015 in both Georgia and South Carolina and in 2016 in Georgia (Table 2). In 2016, symptoms of Pythium stem and root rot developed on a few plants between 6 April and 18 May in South Carolina; these plants were excluded from the Fusarium wilt data. Two isolates of Pythium were identified as $P$. aphanidermatum based on the nucleotide sequences in the internal transcribed spacer (ITS) region amplified with primers ITS 1 and 4 and with primers ITS 4 and 5 (Garibaldi et al. 2015; Lookabaugh et al. 2015). In 2015, Pythium spp. were isolated from plants with symptoms of wilting and stunting that appeared within 3 weeks after the first transplanting date in South Carolina, so data from the first two ratings were excluded from the Fusarium wilt data.

Transplanting dates. Incidence of Fusarium wilt at the end of the season (referred to henceforth as final incidence) was significantly $(P \leq 0.01)$ lower with the latest transplanting date than with the two earlier transplanting dates in all four experiments (Table 2). In addition, final incidence did not differ significantly between the first two planting dates. The only difference between years occurred in Georgia at the latest date, when final incidence was higher in 2016 than in 2015. In both years, final incidence was $<50 \%$ in Georgia for the last transplanting date, while final incidence for the two earlier dates was $>87 \%$. The largest difference between early and late transplanting was observed in 2015 in South Carolina, a difference of $70 \%$ (Table 2).

Table 3. Incidence (\%) of Fusarium wilt at the end of the season on three cultivars of triploid watermelon planted in soil infested with Fusarium oxysporum f. sp. niveum

\begin{tabular}{lccccc}
\hline & \multicolumn{2}{c}{ South Carolina } & & \multicolumn{2}{c}{ Georgia } \\
\cline { 2 - 3 } \cline { 5 - 6 } Cultivar & $\mathbf{2 0 1 5}$ & $\mathbf{2 0 1 6}$ & & $\mathbf{2 0 1 5}$ & $\mathbf{2 0 1 6}$ \\
\hline Citation & $71.5 \mathrm{a}^{\mathrm{z}}$ & 35.7 & & $84.8 \mathrm{a}$ & $91.8 \mathrm{a}$ \\
Fascination & $48.5 \mathrm{~b}$ & 36.1 & & $67.0 \mathrm{~b}$ & $75.1 \mathrm{~b}$ \\
Melody & $42.7 \mathrm{~b}$ & 36.7 & & $80.7 \mathrm{ab}$ & $79.9 \mathrm{ab}$ \\
Probability & 0.01 & NS & & 0.01 & 0.0051
\end{tabular}

${ }^{\mathrm{z}}$ Means within a column with the same letter are not significantly different, Fisher's protected least-significant difference test evaluated at the probability indicated below each column.

Table 2. Incidence of Fusarium wilt at the end of the season and area under the disease progress curve (AUDPC) for triploid watermelon grown in soil infested with Fusarium oxysporum f. sp. niveum

\begin{tabular}{|c|c|c|c|c|c|c|c|c|c|c|c|c|}
\hline \multirow{4}{*}{$\begin{array}{l}\text { Transplanting } \\
\text { date }\end{array}$} & \multirow{2}{*}{\multicolumn{4}{|c|}{ Final incidence $(\%)$}} & \multicolumn{4}{|c|}{ South Carolina } & \multicolumn{4}{|c|}{ Georgia } \\
\hline & & & & & \multicolumn{2}{|c|}{2015} & \multicolumn{2}{|c|}{2016} & \multicolumn{2}{|c|}{2015} & \multicolumn{2}{|c|}{2016} \\
\hline & \multicolumn{2}{|c|}{ South Carolina } & \multicolumn{2}{|c|}{ Georgia } & \multirow{2}{*}{$\begin{array}{l}\text { Days per } \\
\text { epidemic }\end{array}$} & \multirow{2}{*}{$\begin{array}{l}\text { Relative } \\
\text { AUDPC }\end{array}$} & \multirow{2}{*}{$\begin{array}{l}\text { Days per } \\
\text { epidemic }\end{array}$} & \multirow{2}{*}{$\begin{array}{l}\text { Relative } \\
\text { AUDPC }\end{array}$} & \multirow{2}{*}{$\begin{array}{l}\text { Days per } \\
\text { epidemic }\end{array}$} & \multirow{2}{*}{$\begin{array}{l}\text { Relative } \\
\text { AUDPC }\end{array}$} & \multirow{2}{*}{$\begin{array}{l}\text { Days per } \\
\text { epidemic }\end{array}$} & \multirow{2}{*}{$\begin{array}{l}\text { Relative } \\
\text { AUDPC }\end{array}$} \\
\hline & 2015 & 2016 & 2015 & 2016 & & & & & & & & \\
\hline Early & $81.9 \mathrm{a}^{\mathrm{z}}$ & $57.3 \mathrm{a}$ & $99.8 \mathrm{a}$ & $95.6 \mathrm{a}$ & 106 & $33.5 \mathrm{a}$ & 87 & 18.8 & 72 & $88.7 \mathrm{a}$ & 68 & $66.3 \mathrm{a}$ \\
\hline Middle & $63.4 \mathrm{a}$ & $38.9 \mathrm{a}$ & $87.4 \mathrm{a}$ & $94.1 \mathrm{a}$ & 91 & $25.8 \mathrm{a}$ & 65 & 15.1 & 73 & $62.4 \mathrm{~b}$ & 68 & $60.7 \mathrm{a}$ \\
\hline Late & $11.3 \mathrm{~b}$ & $15.3 \mathrm{~b}$ & $24.2 b^{*}$ & $46.4 \mathrm{~b}^{*}$ & 63 & $2.6 \mathrm{~b}$ & 36 & 6.9 & 50 & $16.7 \mathrm{c}$ & 46 & $32.6 \mathrm{~b}$ \\
\hline Probability & 0.0001 & 0.01 & 0.0002 & 0.0001 & - & 0.0003 & - & NS & - & 0.0001 & - & 0.0001 \\
\hline
\end{tabular}

${ }^{\mathrm{z}}$ Means within a column with the same letter are not significantly different, Fisher's protected least-significant difference test evaluated at the probability indicated below each column. *Means differ between years, Fisher's protected least-significant difference test, $P=0.0002$. 
Because the late transplanting date was 6 weeks after the early transplanting date, AUDPC values were adjusted for the different lengths of the epidemics that occurred on plants transplanted at different times. In three experiments, both 2015 experiments and the 2016 experiment in Georgia, AUDPC for the earliest transplanting date was higher than AUDCP for the latest transplanting date $(P \leq$ 0.0003 ) (Table 2). In addition, mean AUDPC values for the early and midseason transplanting dates in South Carolina (25.6 and 20.1 , respectively) were significantly higher $(P=0.0005)$ than the AUDCP for the late transplanting date (4.5) averaged across the 2015 and 2016 experiments. In Georgia in 2015, AUDPC for the midseason transplanting date was smaller than the AUDPC for the early transplanting date, but this was the only experiment in which AUDPCs for the midseason and early transplanting dates differed (Table 2).

Cultivars. Final incidence of Fusarium wilt at the end of the season was less on Fascination, a cultivar resistant to $F$. oxysporum f. sp. niveum race 1 , than on Citation, a susceptible cultivar, in three of the four experiments, i.e., both experiments in Georgia and in the 2015 experiment in South Carolina (Table 3). In both years, final disease incidence on Melody was intermediate and did not differ from incidence on the other two cultivars in Georgia. Final incidence on Melody was similar to incidence on Fascination in South Carolina in 2015. In 2016 in South Carolina, final incidence did not differ among cultivars.

Soil temperature. Soil temperatures ranged from 5.0 to $45.6^{\circ} \mathrm{C}$ at 10 -cm depth in Cordele, GA and from 8.2 to $48.5^{\circ} \mathrm{C}$ at $5-\mathrm{cm}$ depth in Charleston, SC (Table 4). The lowest minimum and the greatest maximum temperatures occurred in 2015 within 4 weeks of the first and last transplanting dates, respectively. Mean soil temperature on the day of transplanting and soil temperatures averaged over the 2- or 4-week periods after transplanting were negatively correlated with final disease incidence $(r=-0.640,-0.666$, and $-0.737, P=0.025$, 0.018 , and 0.006 , respectively). Because mean soil temperature during the 4 weeks after transplanting (abbreviated T4) had the largest Pearson correlation coefficient, this temperature measurement was used to predict final disease incidence (FDI). It predicted FDI very well in Georgia (adjusted $R^{2}=0.96$ ) and reasonably well in South Carolina (adjusted $R^{2}=0.54$ ) (Fig. 1). The resulting regression equations were FDI $=-701.0+73.8(\mathrm{~T} 4)-1.7(\mathrm{~T} 4)^{2}$ for Georgia and FDI $=332.4-11.8(\mathrm{~T} 4)$ for South Carolina. Temperatures $>27^{\circ} \mathrm{C}$ in Georgia and $>25.5^{\circ} \mathrm{C}$ in South Carolina reduced FDI at the last transplanting date (Fig. 1).

Marketable yields. In South Carolina, both the number and weight of marketable fruit, summed over the six harvests, was approximately twice as great in 2016 as in 2015 (F-statistic for main effect of year significant, $P \leq 0.0001)$. Mean marketable weight was only $7.4 \mathrm{t} / \mathrm{ha}$ in 2015 but $17.8 \mathrm{t} / \mathrm{ha}$ in 2016 , while the mean number of marketable fruit per hectare increased from 518 to 1,343 . Both marketable weight and marketable number of fruit were similar for the early, midseason, and late transplanting dates (F-statistics for main effects of date not significant, $P=0.12$ and $P=0.16$ for weight and number, respectively).

In Georgia, yields in 2015 were poor because of severe Fusarium wilt and sunburn on fruit exposed by death of foliage. Only eight of the 36 plots produced marketable-sized fruit. There were no significant differences among planting dates or cultivars (Table 5). Yields in Georgia were greater in 2016 than in 2015. In 2016, transplanting date affected the number and weight of marketable fruit (F-statistics for main effects of date significant, $P \leq 0.01)$. Mean numbers of marketable fruit were significantly greater $(P=0.04)$ for the last transplanting date $(2,092$ fruit/ha) than for the first two dates $(717$ and 120 fruit/ha for the early and midseason transplanting dates, respectively), which did not differ from each other. Similarly, marketable weights for the last $(8.2 \mathrm{t} / \mathrm{ha}$ ) and first $(3.0 \mathrm{t} / \mathrm{ha})$ transplanting dates were greater than for the midseason $(0.7 \mathrm{t} / \mathrm{ha})$ transplanting date $(P<0.05)$.

In both states, watermelon cultivars produced differing numbers and weights of marketable fruit (F-statistics for main effects of cultivar significant, $P<0.005$ for both variables in all three experiments) (Table 5). There were no interactions of cultivar with transplanting date or year. In all experiments, weights and numbers of marketable fruit were significantly greater $(P \leq 0.002)$ for Fascination and Melody than for Citation, and yields of Melody and Fascination did not differ from each other. In South Carolina, Fascination and Melody consistently produced a higher percentage of marketable-sized fruit, i.e., fruit weighing $\geq 4.54 \mathrm{~kg}$ apiece, than Citation $(P \leq 0.006)$ (Table 5). Citation produced a greater percentage of marketablesized fruit in 2016 than in 2015, but the percentage of marketable fruit did not differ between years for Fascination and Melody. A similar trend was observed in Georgia, but differences among cultivars were not significant due to the large variation between the 59 plots from which fruit were harvested and the 49 plots that yielded no marketable-sized fruit.

For South Carolina yields, the distribution of fruit by size, i.e., individual fruit weight, was examined with multivariate analysis of variance. In both 2015 and 2016, fruit sizes differed among cultivars $(P \leq 0.0002)$. Fascination and Melody consistently produced more midsized fruit, i.e., fruit weighing $6.2 \mathrm{~kg}$ to $7.9 \mathrm{~kg}$ apiece, than Citation $(P \leq 0.0065)$ (Fig. 2). In 2015, Fascination produced more small fruit weighing 4.5 to $6.1 \mathrm{~kg}$ than the other two cultivars, but in 2016, all cultivars produced similar amounts of small fruit. In 2015, Melody produced more large fruit $(\geq 8.0 \mathrm{~kg})$ than Citation, and in 2016, Fascination produced more large fruit than Citation $(P \leq$ 0.001). In both years, Citation produced more extra-small fruit ( $<4.5 \mathrm{~kg}$ apiece) than the other two cultivars, and in 2016, Melody

Table 4. Mean, minimum (min), and maximum (max) soil temperatures $\left({ }^{\circ} \mathrm{C}\right)$ recorded between transplanting and 4 weeks after transplanting in Georgia and South Carolina field experiments ${ }^{\mathrm{z}}$

\begin{tabular}{|c|c|c|c|c|c|c|c|c|c|c|}
\hline \multirow[b]{2}{*}{ Location, Year } & \multirow[b]{2}{*}{ Transplanting date } & \multicolumn{3}{|c|}{ Transplanting day } & \multicolumn{3}{|c|}{$\begin{array}{l}\text { 2-Week period after } \\
\text { transplanting }\end{array}$} & \multicolumn{3}{|c|}{$\begin{array}{l}\text { 4-Week period after } \\
\text { transplanting }\end{array}$} \\
\hline & & Mean & Min & Max & Mean & Min & Max & Mean & Min & Max \\
\hline Cordele, GA, 2015 & 20 March & 22.9 & 17.0 & 32.0 & 18.6 & 5.0 & 33.0 & 20.6 & 5.0 & 38.0 \\
\hline Cordele, GA, 2015 & 10 April & 24.6 & 20.0 & 34.0 & 22.2 & 13.5 & 39.5 & 22.8 & 12.0 & 41.5 \\
\hline Cordele, GA, 2015 & 1 May & 24.7 & 14.5 & 37.5 & 26.3 & 12.5 & 42.0 & 27.7 & 12.5 & 45.6 \\
\hline Cordele, GA, 2016 & $21 \mathrm{March}$ & 21.2 & 15.0 & 26.0 & 19.5 & 9.5 & 31.0 & 19.7 & 9.7 & 32.0 \\
\hline Cordele, GA 2016 & 11 April & 20.3 & 14.5 & 28.5 & 21.8 & 14.0 & 37.0 & 24.6 & 14.0 & 41.0 \\
\hline Cordele, GA 2016 & 2 May & 28.5 & 23.5 & 35.5 & 27.3 & 16.5 & 40.5 & 27.7 & 16.5 & 40.5 \\
\hline Charleston, SC, 2015 & 18 March & 22.4 & 21.9 & 22.9 & 20.3 & 8.3 & 33.7 & 22.9 & 8.2 & 39.9 \\
\hline Charleston, SC, 2015 & 8 April & 27.6 & 20.6 & 37.8 & 25.4 & 15.5 & 39.9 & 24.6 & 14.9 & 39.9 \\
\hline Charleston, SC, 2016 & 28 April & 24.8 & 19.2 & 32.6 & 23.3 & 14.2 & 37.2 & 25.8 & 14.2 & 48.5 \\
\hline Charleston, SC, 2016 & 17 March & 25.7 & 21.5 & 33.4 & 22.0 & 10.3 & 34.1 & 21.9 & 10.3 & 34.1 \\
\hline Charleston, SC, 2016 & 7 April & 23.9 & 18.0 & 33.0 & 20.7 & 12.8 & 32.9 & 24.5 & 12.8 & 32.9 \\
\hline Charleston, SC, 2015 & 26 April & 28.8 & 20.3 & 39.1 & 27.9 & 17.1 & 40.5 & 27.1 & 17.1 & 40.5 \\
\hline
\end{tabular}

${ }^{\mathrm{z}}$ Temperatures were measured in raised beds mulched with black polyethylene at 10 -cm depth every $2 \mathrm{~h}$ and 5 -cm depth every hour in Georgia and South Carolina, respectively. 
produced more extra-small fruit than Fascination $(P \leq 0.02)$ (Fig. 2). In both years, transplanting date also affected the size distribution of marketable fruit in South Carolina $(P \leq 0.04)$, but differences among transplanting dates were not consistent between years for any fruit size (data not shown).

In 2016, the percentages of the different sizes of marketable fruit produced by Fascination and Melody in South Carolina were lower than the expected size distribution for these two cultivars (Table 1, Fig. 2). The percentage of small (60-count) and medium (45-count) fruit on Melody plants was higher (range of 54 to $70 \%$ ) and lower (15 to $35 \%$ ), respectively, than the $10 \%$ and $70 \%$ expected ( $t$ tests, $P \leq 0.05$ and 0.02 , respectively). This shift toward smaller fruit was significant at all three planting dates (data not shown). The percentage of large fruit, which ranged from 11 to $16 \%$ across the three transplanting dates, did not differ significantly from the expected $20 \%$. At the early transplanting date, Fascination produced significantly $(P=0.05)$ fewer large fruit (36-count) than expected ( 9 versus $20 \%)$, and at the midseason transplanting date, Fascination produced more small fruit $(P=0.01)$ and fewer medium-sized fruit $(P=0.02)$ than expected (52\% versus $25 \%$ and $33 \%$ versus $50 \%$, respectively). No differences in the size distribution of Citation fruit were observed. Fruit size distribution in 2015 did not differ from the expected.

In South Carolina, value of the harvested fruit was more than double in $2016(\$ 6,584 /$ ha $)$ than in $2015(\$ 2,563 /$ ha $)(P<0.0064)$. Value differed significantly by cultivar $(P=0.0001)$, just as the yield did. The mean value of fruit produced by Fascination and Melody did not differ, but the values for these cultivars were more than two times greater than the value for Citation (Table 6). Crop value did not differ significantly by transplanting date in South Carolina $(P=0.60)$. In Georgia in 2016, value differed by cultivar and transplanting date $(P<0.0006)$. The value of fruit produced by Fascination and Melody did not differ, but the values for these cultivars were 10 times greater than the value for Citation. Crop value differed for all transplanting dates and was highest for the latest, intermediate for the earliest, and lowest for the midseason transplanting date $(P=0.03)$.

\section{Discussion}

Changing planting date is a widely recommended cultural practice to avoid plant diseases (Kemble et al. 2018). Transplanting susceptible watermelons into soil that has warmed above the critical temperature of $27^{\circ} \mathrm{C}$ reduced the number of plants with symptoms of Fusarium wilt and increased marketable yields. In a previous study done in the same field used in the South Carolina experiments, Fusarium wilt reached a maximum of $48 \%$ when transplants of Fascination were set on 8 April 2013 (Keinath and Hassell 2014b). Those results exactly matched the $48 \%$ final disease incidence for Fascination for the midseason transplanting date of 8 April 2015. In another study done in the same field, final disease incidence for the Fusarium

Table 5. Yield of unblemished, marketable-sized triploid watermelon fruit produced by three cultivars grown in soil infested with Fusarium oxysporum f. sp. niveum

\begin{tabular}{|c|c|c|c|c|c|c|c|}
\hline \multirow[b]{2}{*}{ Cultivar } & \multirow[b]{2}{*}{ Year } & \multicolumn{3}{|c|}{ South Carolina } & \multicolumn{3}{|c|}{ Georgia } \\
\hline & & $\begin{array}{c}\text { Marketable weight } \\
\text { (t/ha) }\end{array}$ & $\begin{array}{c}\text { Marketable } \\
\text { number/ha }\end{array}$ & $\begin{array}{c}\text { Percentage } \\
\text { marketable size }\end{array}$ & $\begin{array}{c}\text { Marketable weight } \\
\text { (t/ha) }\end{array}$ & $\begin{array}{l}\text { Marketable } \\
\text { number/ha }\end{array}$ & $\begin{array}{c}\text { Percentage } \\
\text { marketable size }\end{array}$ \\
\hline Citation & 2015 & $2.0 \mathrm{~B}^{\mathrm{w}}$ & $163 \mathrm{~B}$ & $12.7 \mathrm{~B}^{\mathrm{x}}$ & $1.3 \mathrm{~A}$ & $249 \mathrm{~A}$ & n.d. ${ }^{y}$ \\
\hline Fascination & 2015 & $11.4 \mathrm{~A}$ & $794 \mathrm{~A}$ & $65.5 \mathrm{~A}$ & $4.4 \mathrm{~A}$ & $847 \mathrm{~A}$ & n.d. \\
\hline Melody & 2015 & $11.3 \mathrm{~A}$ & $747 \mathrm{~A}$ & $56.2 \mathrm{~A}$ & $1.4 \mathrm{~A}$ & $249 \mathrm{~A}$ & n.d. \\
\hline Citation & 2016 & $12.2 \mathrm{~b}$ & $997 \mathrm{a}$ & $43.2 b^{x}$ & $0.8 \mathrm{~b}$ & $120 \mathrm{~b}$ & $12.0 \mathrm{a}$ \\
\hline Fascination & 2016 & $21.7 \mathrm{a}$ & $1546 \mathrm{~b}$ & $71.8 \mathrm{a}$ & $4.4 \mathrm{a}$ & $1435 \mathrm{a}$ & $47.7 \mathrm{a}$ \\
\hline Melody & 2016 & $20.2 \mathrm{a}$ & $1525 \mathrm{~b}$ & $62.7 \mathrm{a}$ & $5.2 \mathrm{a}$ & $1195 \mathrm{a}$ & $48.2 \mathrm{a}$ \\
\hline Probability & & 0.0052 & 0.0136 & 0.0136 & 0.0057 & 0.0022 & $\mathrm{NS}^{\mathrm{z}}$ \\
\hline
\end{tabular}

v Percentage of marketable-size fruit weighing $>4.54 \mathrm{~kg}$ apiece relative to all unblemished fruit harvested.

${ }^{\mathrm{w}}$ Cultivar means within a column with the same uppercase or lowercase letter by year are not significantly different, Fisher's protected least-significant difference test at the probability indicated below each column.

${ }^{x}$ Means differ between years (calculated only for percentage of marketable fruit).

y n.d. = Not enough fruit produced to accurately calculate.

${ }^{\mathrm{z}} \mathrm{NS}=$ not significantly different, $P>0.05$.

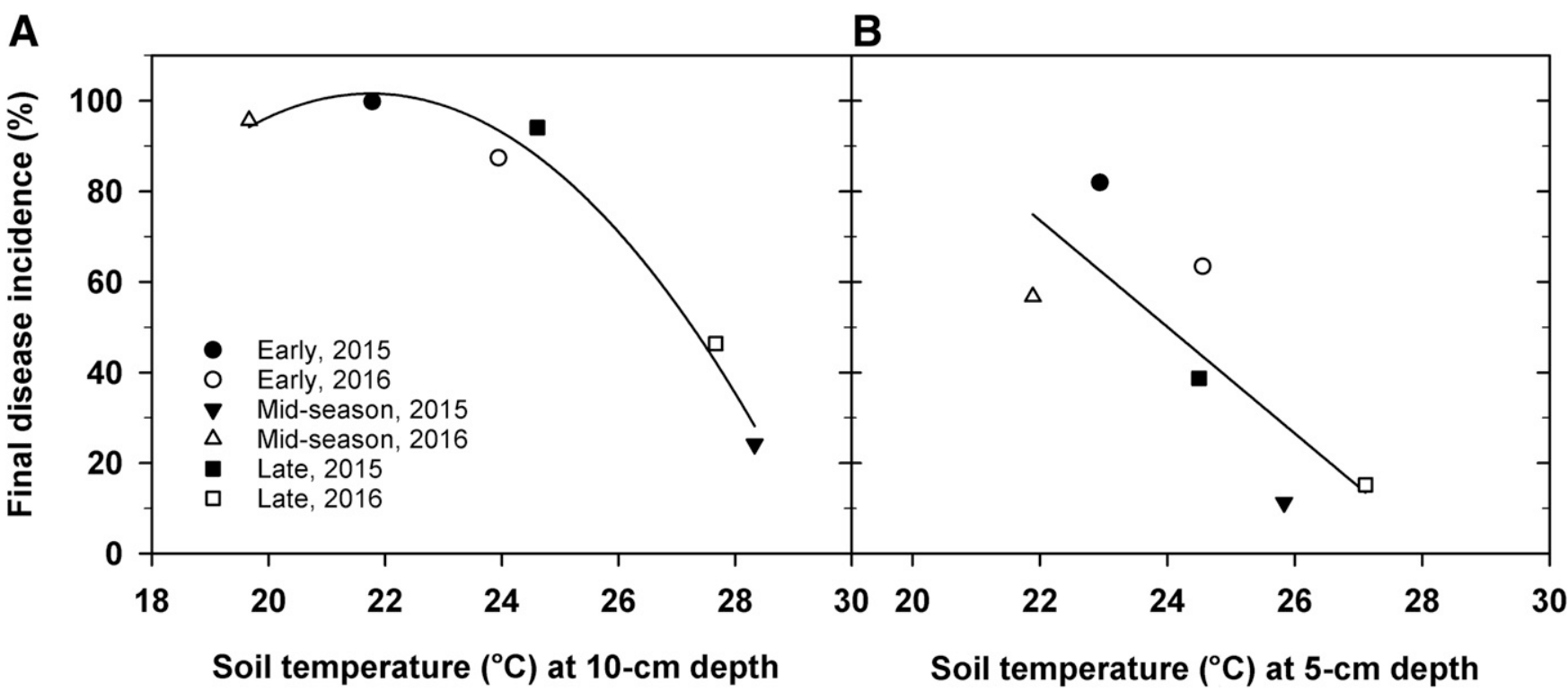

Fig. 1. Relationships between Fusarium wilt incidence at the end of the season and mean soil temperature during the 4 weeks after transplanting. The regression line was quadratic (A) for Georgia (adjusted $R^{2}=0.96$ ) and linear (B) for South Carolina (adjusted $R^{2}=0.54$ ). 
wilt-susceptible cultivar Sugar Heart was $73 \%$ and $4 \%$ when transplanted on 10 April 2007 and 2 May 2008, respectively. In that same study, final incidence on cultivar Revolution, which is moderately resistant to $F$. oxysporum f. sp. niveum race 1, was $35 \%$ in 2007 and $0.4 \%$ in 2008 . Clearly, the effect of temperature on wilt incidence is independent of any resistance to Fusarium wilt a cultivar might possess.

The mean temperatures at which wilt incidence decreased in the current study, approximately 26 to $28^{\circ} \mathrm{C}$, were slightly lower than reported by Walker (1941), who concluded that "infection declines rapidly above $30^{\circ} \mathrm{C}$." In his study, Walker tested constant temperatures, whereas the temperature thresholds determined in the current study were based on mean hourly temperatures measured in the field (Table 4). Soil temperatures over the 4-week period after transplanting were more significantly associated with final wilt incidence than temperatures on the day of transplanting or during the 2 weeks after transplanting. Based on this association, infection may occur over a period that is at least 4 weeks long after transplanting. Walker (1941) also investigated the effects of constant temperature on growth of watermelon and $F$. oxysporum $\mathrm{f}$. sp. niveum. Watermelon seedlings grew most rapidly at 31 to $33^{\circ} \mathrm{C}$. F. oxysporum f. sp. niveum grew optimally at $26.5^{\circ} \mathrm{C}$, with only slight reductions in colony diameter between $32.5^{\circ} \mathrm{C}$ and $21^{\circ} \mathrm{C}$, while colony diameter was noticeably smaller at $16^{\circ} \mathrm{C}$. Thus, it is likely that temperatures $<27^{\circ} \mathrm{C}$ favor the pathogen over the host or increase host susceptibility to infection by $F$. oxysporum f. sp. niveum.

New information gained in this study on the effects of temperature on Fusarium wilt of watermelon may be useful for other scientists concerned with this disease. The variability associated with disease expression, pathogenicity testing for race determination, and cultivar evaluation against Fusarium wilt is well documented (Bruton et al. 2010; Walker 1941). Researchers should attempt to maintain average soil temperatures below $27^{\circ} \mathrm{C}$ during the infection period. At a minimum, temperatures should be documented, so that mean levels of Fusarium wilt can be compared among repeated greenhouse tests or field seasons.

Cultivar selection is an important component of an integrated management strategy for Fusarium wilt of watermelon. Melody was identified as a cultivar that is tolerant of Fusarium wilt, as its disease ratings often were similar to those of the susceptible cultivar Citation, while its yields were much greater. Tolerance in Melody to Fusarium wilt races 1 and 2 also was noted by Everts and Hochmuth (2011) in an evaluation in Delaware, where Melody and Fascination had the greatest yield by weight of 26 cultivars. It is possible that Melody contains one or more genes for resistance to Fusarium wilt that differ from the recently identified gene associated with resistance to race 1 , since final wilt incidence for Melody in 2015 in South Carolina was similar to wilt incidence of the race 1-resistant cultivar Fascination (Lambel et al. 2014). Melody and Fascination also did not differ in wilt incidence in Delaware (Everts and Hochmuth 2011, 2012).

Even though only three cultivars of triploid watermelon were tested in this study, choosing cultivars that produce medium to large fruit (fruit expected to weigh $>6 \mathrm{~kg}$ apiece), like Fascination or Melody, may ensure that the fruit produced by diseased plants will reach marketable size (4.5 kg apiece). In some plots, plants that survived despite infection by $F$. oxysporum $\mathrm{f}$. sp. niveum were stressed to a degree that reduced fruit yields to below marketable standards. Although fruit of Melody were consistently smaller than expected, a majority of the fruit, $59 \%$, reached marketable size. Conversely, considerably less than half of the fruit produced by the smallfruited cultivar Citation were marketable size, although the fruit that were marketable reached the expected sizes. The percentage of marketable-sized fruit that Fascination produced in South Carolina in this study, 65 to $72 \%$, was greater than in a previous study done

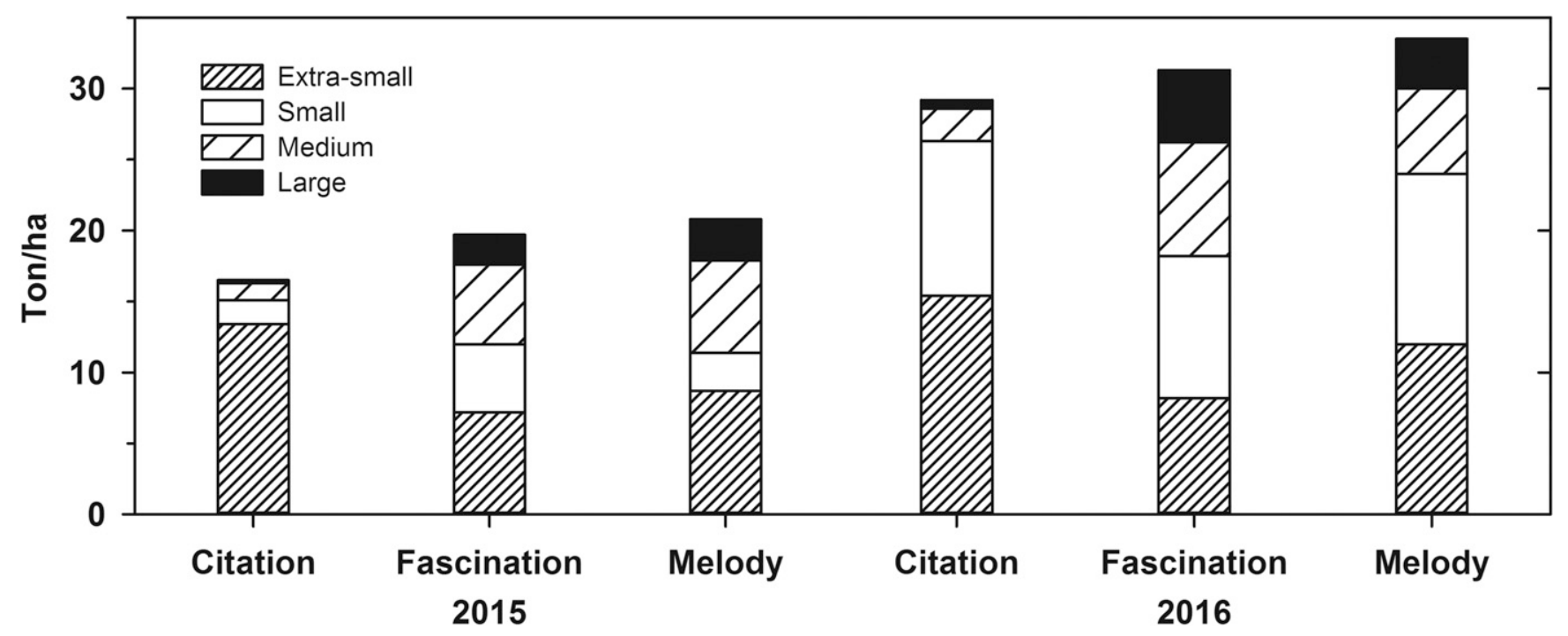

Fig. 2. Distribution of sizes of unblemished, triploid watermelon fruit produced by three cultivars grown in Fusarium-infested soil in South Carolina in 2015 and 2016.

Table 6. Value ( $\$ / \mathrm{ha})$ of marketable-sized triploid watermelon fruit ${ }^{\mathrm{w}}$

\begin{tabular}{|c|c|c|c|c|c|}
\hline Cultivar & South Carolina $^{x}$ & Georgia $^{y}$ & Transplanting date & South Carolina ${ }^{x}$ & Georgiay \\
\hline Citation & $2,462 b^{z}$ & $203 \mathrm{~b}$ & Early & 4,502 & $1,322 \mathrm{~b}$ \\
\hline Fascination & 5,427 a & $2,821 \mathrm{a}$ & Middle & 4,665 & $239 c$ \\
\hline Melody & $5,531 \mathrm{a}$ & $2,206 \mathrm{a}$ & Late & 3,876 & $3,908 \mathrm{a}$ \\
\hline Probability & 0.0002 & 0.0016 & Probability & NS & 0.0319 \\
\hline
\end{tabular}


in the same field, when the percentage was just $49 \%$ (Keinath and Hassell 2014b).

Integrated management of Fusarium wilt will remain an important tactic in the near future. Although resistance to $F$. oxysporum $\mathrm{f}$. sp. niveum race 2 has been identified and mapped in Citrullus amarus (syn. C. lanatus var. citroides), no cultivars possessing these resistance genes are available currently (Branham et al. 2017; Wechter et al. 2012). In addition, race 3 of $F$. oxysporum f. sp. niveum was recently identified in Florida and Georgia (Amaradasa et al. 2018; Petkar and Ji 2017). As no source of resistance has been identified to race 3 , transplanting into warm soil can be used as a nonchemical management technique. Additional approaches to warming soil during the spring, such as using clear polyethylene mulch that is then spray painted black before transplanting, or laying mulch well in advance of transplanting to warm soil, may prove useful in managing Fusarium wilt.

\section{Acknowledgments}

We thank V. B. DuBose, C. D. Conrad, M. D. Rushton, B. Dutta, M. Brannon, M. Foster, and M. Donahoo for technical assistance and Syngenta for donating seed.

\section{Literature Cited}

Amaradasa, B. S., Beckham, K., Dufault, N., Sanchez, T., Ertek, T. S., Iriarte, F., Paret, M., and Ji, P. 2018. First report of Fusarium oxysporum f. sp. niveum race 3 causing wilt of watermelon in Florida, U.S.A. Plant Dis. 102:1029.

Branham, S. E., Levi, A., Farnham, M. W., and Wechter, W. P. 2017. A GBS-SNPbased linkage map and quantitative trait loci (QTL) associated with resistance to Fusarium oxysporum f. sp. niveum race 2 identified in Citrullus lanatus var. citroides. Theor. Appl. Genet. 130:319-330.

Bruton, B. D., Fish, W. W., Vivoda, E., Gabor, B., and Everts, K. L. 2010. On the reliability of Fusarium oxysporum f. sp. niveum research: Do we need standardized testing methods? Pages 222-225 in: Cucurbitaceae 2010 Proceedings. J. A. Thies, S. Kousik, and A. Levi, eds. American Society for Horticultural Science, Alexandria, VA.

Davis, A. R., Perkins-Veazie, P., Sakata, Y., Lopez-Galarza, S., Maroto, J. V., Lee, S. G., Huh, Y. C., Sun, Z., Miguel, A., King, S. K., Cohen, R., and Lee, J. M. 2008. Cucurbit grafting. Crit. Rev. Plant Sci. 27:50-74.

Everts, K. L., and Hochmuth, M. 2011. Field evaluation of triploid cultivars for resistance to Fusarium wilt of watermelon in Delaware, 2010. Plant Dis. Manage. Rep. 5:V175.

Everts, K. L., and Hochmuth, M. E. 2012. Evaluation of triploid cultivars for resistance to Fusarium wilt of watermelon, 2011. Plant Dis. Manage. Rep. 6: V014.

Garibaldi, A., Gilardi, G., Ortu, G., and Gullino, M. L. 2015. Root rot of spinach in southern Italy caused by Pythium aphanidermatum. Plant Dis. 99:159.
Horton, D. 2015. Georgia Pest Management Handbook. 2015 Commercial Edition. Univ. Georgia Coop. Ext. Special Bull. 28.

Keinath, A. P., and DuBose, V. B. 2009. First report of Fusarium oxysporum f. sp. niveum race 2 in South Carolina watermelon fields. (Abstr.). Phytopathology 99:S63.

Keinath, A. P., and Hassell, R. L. 2014a. Control of Fusarium wilt of watermelon by grafting onto bottlegourd or interspecific hybrid squash despite colonization of rootstocks by Fusarium. Plant Dis. 98:255-266.

Keinath, A. P., and Hassell, R. L. 2014b. Suppression of Fusarium wilt caused by Fusarium oxysporum $\mathrm{f}$. sp. niveum race 2 on grafted triploid watermelon. Plant Dis. 98:1326-1332.

Keinath, A. P., Hassell, R. L., Everts, K. L., and Zhou, X.-G. 2010. Cover crops of hybrid common vetch reduce Fusarium wilt of seedless watermelon in the eastern United States. Plant Health Prog. doi.org/10.1094/PHP-2010-091401-RS

Kemble, J. M., Meadows, I. M., Jennings, K. M., and Walgenbach, J. F., eds. Revised 2018. Southeastern U.S. Vegetable Crop Handbook. Available online at www.growingproduce.com/southeasternvegetablecrophandbook/

Lambel, S., Lanini, B., Vivoda, E., Fauve, J., Wechter, W. P., Harris-Shultz, K. R., Massey, L., and Levi, A. 2014. A major QTL associated with Fusarium oxysporum race 1 resistance identified in genetic populations derived from closely related watermelon lines using selective genotyping and genotypingby-sequencing for SNP discovery. Theor. Appl. Genet. 127:2105-2115.

Lookabaugh, E. C., Ivors, K. L., and Shew, B. B. 2015. Mefenoxam sensitivity, aggressiveness, and identification of Pythium species causing root rot on floriculture crops in North Carolina. Plant Dis. 99:1550-1558.

Martyn, R. D. 2014. Fusarium wilt of watermelon: 120 years of research. Hortic. Rev. (Am. Soc. Hortic. Sci.) 42:349-442.

Martyn, R. D. 2017. Fusarium wilt of watermelon. Pages 38-40 in: Compendium of Cucurbit Diseases and Pests, 2nd Ed. A. P. Keinath, W. M. Wintermantel, and T. A. Zitter, eds. American Phytopathological Society, St. Paul, MN.

Petkar, A., and Ji, P. 2017. Diversity of Fusarium oxysporum f. sp. niveum from watermelon in Georgia. (Abstr.) Phytopathology. 107:S5.123.

Porter, D. R. 1932. Some environmental relations of watermelon wilt Phytopathology 22:848-852.

Walker, M. N. 1941. Fusarium wilt of watermelons. I. Effect of soil temperature on the wilt disease and the growth of watermelon seedlings. Univ. Fla. Agric. Exp. Stn. Bull. 363.

Wechter, W. P., Kousik, C., McMillan, M., and Levi, A. 2012. Identification of resistance to Fusarium oxysporum f. sp. niveum race 2 in Citrullus lanatus var. citroides plant introductions. HortScience 47:334-338.

Yetışır, H., Sari, N., and Yücel, S. 2003. Rootstock resistance to Fusarium wilt and effect on watermelon fruit yield and quality. Phytoparasitica 31:163-169.

Zhou, X. G., and Everts, K. L. 2003. Races and inoculum density of Fusarium oxysporum f. sp. niveum in commercial watermelon fields in Maryland and Delaware. Plant Dis. 87:692-698.

Zhou, X. G., Everts, K. L., and Bruton, B. D. 2010. Race 3, a new and highly virulent race of Fusarium oxysporum $\mathrm{f}$. sp. niveum causing Fusarium wilt in watermelon. Plant Dis. 94:92-98. 